\title{
Addressing Transboundary Haze Through Asean: Singapore's Normative Constraints
}

\author{
Helena Muhamad Varkkey
}

\begin{abstract}
Since 1982, Southeast Asia has experienced almost annual 'haze' pollution, caused by smoke from grass, forest and peat fires mostly in Indonesia. The haze affects the health of some 75 million people and the economies of six ASEAN nations. It is the region's first transboundary environmental crisis that ASEAN is attempting to address collectively. ASEAN level interaction is often guided by the ASEAN Way, and a common debate is whether these norms constrain states from interacting effectively at the regional level. This paper will address this debate using interviews and material compiled during fieldwork in Singapore. While Singapore was one of the first countries to propose a common regional approach to the haze, this paper will illustrate how Singapore has in fact been constrained by the ASEAN Way while engaging with Indonesia and ASEAN. This is reflected in terms of its behavior at the ASEAN forum, statements made, and actions taken. As a result, Singapore has often resorted to other means of engagement, like bilateral and track-two engagement. As Singapore is one of the major 'victims' in this equation, this paper serves as important piece of the broader puzzle of why haze management in ASEAN has been less than effective.
\end{abstract}

Keywords: ASEAN Way, Singapore, Indonesia, Transboundary Haze, Regional Cooperation.

\section{Introduction}

As early as mid-1972, the term 'haze' was used by Singaporeans as a general reference to the steadily increasing air pollution that was visible in the developing city, at the time mainly thought to be caused by local vehicle and factory fumes, and the burning of rubbish (Wee, 1973). However, at the end of that year, Singapore experienced a drastic increase in visible pollution, which was later identified as Singapore's first serious episode of transboundary haze. At its worse, Singaporeans in high-rise flats reported 'white smoke' drifting in through their windows (Gan, 1972). Following this, Singapore experienced serious haze episodes in 1982-1983, 1991, 1994, 1997-1998, 2002, 2006 and most recently in 2009 (FranceschHuidobro, 2008). This haze, that usually occurs during National Day season in Singapore (9 August) often casts a dark pallor over that special day (Mulchand [S21], 2010).

This paper will combine material obtained from Singaporean newspapers, publications by the Singaporean government, ASEAN and other agencies, and primary data from semi-structured interviews that I conducted with journalists, government officials, non- 
governmental organizations (NGOs), as well as fellow researchers of this field that are based in Singapore. I argue that while state actors act primarily in their national interests, states who are members of an international or regional community with a common ethos, like ASEAN, will be constrained by that community's normative environment. These actors will therefore strategically use these community norms to justify or encourage certain activity towards fulfilling their national interests.

Dr Euston Quah (2010) from the Economics Faculty at Singapore's Nanyang Technological University that was interviewed for this paper, describes Singapore as having to 'suffer twice' from this transboundary haze. Singapore suffers in terms of citizen health and significant negative impact on the economy. As a small island state, Singapore is especially vulnerable to atmospheric pollution that can blanket the whole country at once. It then suffers again in assistance expenses incurred to Indonesia and ASEAN. In addition, unlike Malaysia which has substantial profitable investments in Indonesian oil palm plantations, Singapore's plantation investments in Indonesia are negligible. Therefore, Singapore does not have any vested interests in the burning activities in these plantations that are the major cause of the haze as well. Singapore's national interests lie primarily in its continued growth as a 'clean and green' global business hub and the well-being of its people. By these calculations, Singapore, even more than Malaysia and Indonesia, bears the brunt of the damage from the haze. This paper therefore aims to illustrate how Singapore has at different times either used norm-based arguments in pursuit of its national interests, or have had its strategic actions constrained by the community norms.

)

\section{Environmental Management Structure}

C

The Ministry of the Environment (now known as the Ministry of Environment and Water Resources or MEWR) is the policy-making body for environmental matters in the Singaporean government, and holds primary responsibility over air quality in the country (Francesch-Huidobro, 2008). The Anti-Pollution Unit (APU), which was established earlier - under the Prime Minister's Office to ensure that economic growth and rapid industrialisation were not achieved at the expense of the environment, was merged with the MEWR and renamed as the Pollution Control Department (PCD) when the ministry was established in 1972.

In 2002, the National Environment Agency (NEA) was established as a statutory board under the MEWR, in charge of operations and the implementation of environmental policies. The Meteorological Service Division (MSD) is under the purview of the NEA, and is directly involved in haze monitoring (Francesch-Huidobro, 2008). The MSD is co-located with the ASEAN Specialised Meteorological Centre (ASMC), whose role was expanded to include the monitoring of fires and haze in 1997 (Woon, 2002). The haze episode of 2004 resulted in the formation of an Inter-Ministry Task Force on Haze (ITFH), chaired by MEWR and comprising representatives from other agencies like the MSD, Ministry of Home Affairs (MOHA), Ministry of Information, and Ministry of Health. 
The Singapore Environment Council (SEC) is a government-initiated NGO that was reestablished in 1995 as an autonomous organization, and performs various coordinating and educational functions, and is an implementer of programmes approved by the MEWR. The Singapore Institute of International Affairs (SIIA) is an NGO that is involved in mainly environmental policy-related dialogue and research, and facilitating information across borders to other think-tanks in the region (Francesch-Huidobro, 2008).

Over the years, the government of Singapore's approach to the haze issue evolved into a multi-pronged strategy involving all these agencies. Singapore tackled the haze on three fronts. Firstly, the NEA and PCD, in collaboration with other agencies, introducing measures to lessen the negative health impact on society. Secondly, the MEWR in collaboration with ministries like the MOFA put into place efforts to collaborate both bilaterally and regionally with the Indonesian government to control the fires. Thirdly, the Singaporean government enlisted the help of the SEC and SIIA to encourage civil society and the international community to apply indirect pressure on the Indonesian government (Francesch-Huidobro, 2008).

\section{Identifying the Source}

Because of its expertise in satellite technology and monitoring stations, Singapore early on had a better understanding of the nature of the haze compared to Malaysia and Indonesia (Lim [S13], 2010). Ever since the first serious episode in 1972, the Singapore Meteorological Service Department (MSD) speculated that the haze was probably caused by fires from Kalimantan and Sumatra in Indonesia, since the dust was coming from the south (Byramji, 1972). Measurements of air quality samples of industrial smoke from Singapore factories confirmed that the source was external (Gan, 1972). The Indonesian fires were confirmed by satellite pictures and Singaporean air crews flying over the region. On the worst days, visibility was reduced from 20 kilometres to 0.6 kilometres, and the haze slowed ferry travel at Singapore's Sentosa Island. The month of April 1983 was reported to be the haziest month in Singapore in 30 years.

Throughout the years, various responses were received by Singaporean authorities from Indonesia as way of explanation from the haze occurrences. During the 1972 episode, Indonesia first denied that there were fires in the Indonesian islands big enough to cast such a thick blanket of haze over Singapore Byramji. Change in wind direction blows away the haze., but later admitted that local shifting cultivation habits in Palembang, Sumatra, which required open burning, was the cause of the haze. In 1982 and 1983, Indonesia reported that thousands of hectares of forests in Kalimantan were reported to have accidentally caught fire as a result of the extreme heat during the dry season. The 1994 fires were reported to have been deliberately started for political reasons by people opposed to the government's timber concession programmes (Hadhi, 1994). Other reasons that were given include fires started from carelessly disposed of cigarette stubs.

Still, Singaporean news reports claim that the fires in Indonesia were worse that the Indonesian government was prepared to admit. While initially believed to be caused primarily by small- 
scale farmers using the slash-and-burn method to clear land (Francesch-Huidobro, 2008), findings by the Centre for Remote Imaging, Sensing and Processing (CRISP) of Singapore in 2004 showed that a majority of the fires in Riau, Sumatra stem from oil palm plantation burning, with only a little coming from primary forest (Geh, 2010). It is well known that there is substantial economic motivation to clear and prepare land for harvest by the much cheaper method of open burning (Lee, 2010).

These plantations fires were dubbed 'annual burn-offs' by the Singaporean media, and coincided with Indonesia's targeted policy during that time of converting millions of hectares of forest into plantations (Francesch-Huidobro, 2008). The recent haze in 2009 was again linked to Indonesian government policy, with the reversal of a year-long moratorium „of the use of peatland forests by palm oil companies (Soeriaatmadja, 2009).

\section{The Cost-Benefit Equation}

Despite heightened public concern over the haze episodes in 1972, 1982-1983, and 1991, PCD spokespersons maintained that there was no need for public alarm over the situation. The reason given was because the haze was not photochemical in nature, and thus was not dangerous to health and did not increase pollution levels in Singapore. The PCD declared that it was not dangerous to be outdoors Byramji. Change in wind direction blows away the haze. Reports in 1984 stated that the levels for all air pollutants in Singapore were generally within the World Health Organization (WHO) standards and the US Environmental Protection Agency (USEPA) Primary Standards. The MEWR reported that eye irritation Jand a slight odour in the air was merely an indication of the origins of the haze; of smoke from fires.

However, faced with increased reports of eye irritation and respiratory problems, and with - the adoption of the Pollution Standards Index (PSI) system based on health indicators, 1994 - Was the first year that the Singaporean government acknowledged that air pollution levels were dangerous to health. The PSI in September 1994 reached 124, rated 'unhealthy' on - the PSI scale (Hadhi, 1994). At its worst, the PSI hit a record high of 226 in 1997 ('very unhealthy').

(1)

Once the government acknowledged that the haze was a health risk, measures to lessen the health impact of the haze on the citizenry was quickly put into place. Based on the ITFH's advice, the MEWR provided three-hourly PSI updates through television and radio media, which was later also made available on the NEA website (Lim, 2010) and via SMS. And even though domestic sources of haze were found to be insignificant, other sources of pollution were closely controlled, like raising penalties on smoky vehicles. The government also set up emergency medical centres in public housing estates (Francesch-Huidobro, 2008), and initiated more academic research on the effect of haze on asthma and other respiratory functions (Liang, 2000).

While the effect of the haze on citizen health was given substantial attention by the Singaporean government, journalists that covered the haze episodes in Singapore observed that the Singaporean government eventually became more focused on the economic impacts 
of the haze. As a country without any notable natural resources, Singapore's 'clean and green' image is very closely linked to its continued development and attractiveness as a global business hub. Therefore, mitigating the haze was placed very high up on Singapore's national interest priority list (Geh, 2010).

Table 1

Total Economic Losses to Singapore During the 1997 Haze (Lower Bound)

\begin{tabular}{lccc}
\hline Type of damage & S\$ Million & USD Million & Percentage \\
\hline Health & 6.00 & 4.00 & 6.20 \\
Tourism & 81.80 & 58.40 & 83.90 \\
Airlines & 9.70 & 6.90 & 9.90 \\
Total damage cost & 97.50 & 69.30 & 100.00 \\
\hline
\end{tabular}

- Azhar Ghani (2010), a former Indonesia Bureau Chief of the Straits Times that was interviewed, notes that government concern over the haze issue went into overdrive after 1997, when the negative link between the haze and Singapore's economy became clearer. Concerns were raised from both the public and government on how the haze had affected business and tourism in Singapore (Fernandez, 1997), with researchers confirming a loss of at least S\$97.5m during the 1997 episode (See Table 1). In a study commissioned by the International Development Research Centre (IDRC), it was concluded that the tourism industry in Singapore suffered the heaviest financial losses, at least $84 \%$ of the total estimated losses of the year as a result of the haze. Airline losses take up almost $10 \%$, with the remaining attributed to health costs (Hon, 1999).

A follow up study in 2006 put estimated losses at \$79 million within just the first hazy month of the year, not least because of the forced closure of Changi airport (Ghani, 2010). Singapore was especially concerned in 2009 about the haze as hazy conditions could affect Singapore's F1 race and the APEC Forum (Gunasingham, 2009a). The haze this time also caused a measurable $20 \%$ increase in the number of patients with haze-related problems.

\section{The Singapore-Indonesia Relationship}

From the beginning, the haze in Singapore was regarded as a very political and sensitive issue. Singapore had a good prior working relationship with Indonesia, even at top leadership level, which it did not want to damage. There is high interdependence between the two countries, as Singapore is especially reliant on Indonesian foreign direct investment, and vice versa (Savage, 2010).

However, the historical relationship between Indonesia and Singapore has been described as 'difficult'. Indonesia's ongoing internal racial tensions had brought to surface a disturbing 
anti-Chinese element which Singapore, as a Chinese-majority state, took personally (Smith, 1999). Most significantly, the Indonesian president once called Singapore a 'little red (Chinese) dot in a sea of (Muslim) green', which was the first time an explicit statement was made out of an implicit understanding (Savage, 2010).

Singapore is also known to be relatively outspoken when commenting on Indonesia's internal affairs. Indonesia never took kindly towards these occurrences. It responded coldly in 1998 when Singapore Mentor Minister Lee Kuan Yew criticized then-Indonesian President Suharto's choice of Jusuf Habibie for vice-president (this being the first direct criticism of Indonesia by the leader of another ASEAN country), and in 1999 when Singapore Prime Minister Goh Chook Tong called on Jakarta to hold elections that would be accepted as fair and legitimate by the Indonesian people (Katsumata, 2004). The Megawati government gave Singapore a taste of its own medicine when it responded to Singapore's demand for stronger action against terrorist suspects taking shelter in Indonesia by citing Indonesia's 'democratic political system', which does not permit arbitrary arrests of the kind that

C) Singapore's International Security Act facilitates (Acharya, 2003).

-

Vague unresolved sovereignty issues also exist between the countries, involving the Riau islands of Batam and Bintan, located very close to Singapore. In the 1960s, Singapore government-linked companies invested heavily in these islands. Now, the islands are a peculiar hybrid of Indonesian-Singaporean social order. The Singapore government's role in these islands have been raised as an election issue in Indonesia, and the islands stand to be set further apart from Jakarta by their inclusion in a Singapore-US free trade agreement in 2002, made possible by the lack of clear-cut rules on the limits of the Singaporean Sovernment's involvement (Phelps, 2004).

Despite these points of contention, relations between Singapore and Indonesia remain amicable. However, the recurring haze issue had added strain between the two countries. - But as my Singaporean interviewees often observe, 'you cannot choose your neighbours', therefore 'divorce', or a total severance of ties is not an option no matter how serious the situation (Mulchand, 2010). Therefore the Singaporean government were relatively careful with its engagement with Indonesia over the issue, especially during the early years (Savage, 2010).

\section{From Quiet Tolerance to Voicing Out}

Since the first episode of the haze, there was significant public outcry and dissatisfaction over what was regarded as the lack of action from both the Singaporean and Indonesian governments in mitigating the haze (Geh, 2010). However, MEWR announced that there was nothing it could do to prevent the haze at the time, as the source was not local. The MOHA Minister Wong Kan Seng reminded the public that it should not be too vocal when condemning Indonesia, as this was not in line with ASEAN norms and values. He stated that the Singaporean government had already been sufficiently assertive over the matter (Chua, 
1997). Tay (1997), the NEA chairman also reminded the public that Indonesia's territorial sovereignty must be respected and assistance must be rendered constructively and quietly, in accordance with the ASEAN Way. MEWR Minister Yeo Cheow Tong even commended President Suharto's apology that came in 1997, saying that it was a welcome and much appreciated surprise; that showed the President's sincere concerns about the ASEAN environment. The Minister stated that Singapore was encouraged by Jakarta's urgency over the situation, citing President Suharto's ban on land clearing as an example (Pereira, 1997).

As a result, Singaporeans felt victimised by the situation (Lim, 2010). They accused the government of prioritising 'saving face' of their neighbour, instead of focusing on the wellbeing of its citizens. As several journalists pointed out, everyone knew where the haze was coming from and why, but no one could openly write about it (Lee, 2010). An opposition MP also ridiculed this approach, saying that if the MEWR minister insists on being polite to the Indonesians, he should consider 'telling them politely' that Singapore would take them to the International Court (for compensation) if the haze problem remains unresolved (Francesch-Huidobro, 2008). This suggestion was thrown out (Chua, 1997), as Singaporean academicians admit that even though the Indonesian president's apology signified the acceptance of moral responsibility by the Indonesian government, legal recourse with Indonesia was unlikely given present ASEAN realities (Tay, 1997).

However eventually, official statements began reflecting public sentiment, which some scholars identify as proof that Singapore chose to break away from the ASEAN norm of non-interference with regards to the haze issue (Lee, 2010). Simon Tay (2007) of the NEA warned that the failure of the Indonesian government to take immediate action would result in the loss of credibility in Indonesian leadership on the regional and international level. The NEA and MOFA also often wrote directly to their counterparts in Indonesia to express concern over the worsening haze situation over the years. In 2003, Minister Lim later released a statement saying that Singapore was communicating with Malaysia and Brunei

over haze issues, significantly excluding Indonesia from the list.

The Singaporean Prime Minister Lee Hsien Loong also expressed his disappointment directly to President Susilo Bambang Yudhoyono in a letter in 2006, which was released to the press. The Indonesian president responded quickly to this letter with another apology to the governments of Singapore and Malaysia, 'even though this was not an intentional act by Indonesia' (Ghani, 2006). However, frustrated that these apologies were not translating into action (Sun, 2010), Singapore decided to host an emergency meeting between Singapore, Brunei, Indonesia, Malaysia and Thailand to discuss the haze and "put pressure on Indonesia' (Ghani, 2006). This unilateral move angered Indonesia, and the very same day the Singaporean-sponsored meeting was announced, the Indonesian President announced that Indonesia would host the meeting instead (Ghani, 2010).

As a way to further indirectly pressure and embarrass Indonesia, Singapore also invited Indonesian officials to attend its F1 race in 2009 to see how the haze had affected the 
event. In 2010, the Singaporean Minister at the MEWR expressed his disappointment to the press that despite many reminders to the Indonesians to pay attention to the hotspots, they continue to recur. He said that if the situation worsens, Singapore may consider registering their concerns on stronger terms (Channel NewsAsia, 2010). Singaporean officials however tell how their colleagues in Indonesia would get visibly upset when Singapore expresses its displeasure in these ways.

\section{Strategic Action}

An international community is characterised by a common ethos and high interaction density, and Schimmelfennig argues that the community's normative environment would have a constraining effect on strategic action (Schimmelfennig, 2002). Accordingly, as a founding member of ASEAN, Singapore's interaction with other members of the grouping should be influenced by the community ethos; that of the ASEAN Way. As described in the previous section, there have been several instances where Singapore has put pressure

1 and embarrassed Indonesian officials in attempt to encourage more positive action from Indonesia on haze mitigation. However, in accordance with the good neighbourliness norm of the region, Singapore largely placed higher priority on 'helping' rather than 'shaming' the Indonesian government over the fires (Francesch-Huidobro, 2008).

Especially during the early years of the crisis, Singapore was eager to help and engage with Indonesia on haze mitigation under the ASEAN umbrella. Several of my interviewees pointed out that this was primarily because Singapore did not want to be the only country financing mitigation efforts. Singapore did not want to be 'penalised' by being singled out Cto provide assistance just because it was the most developed country in the ASEAN region. - This mindset can be explained using Schimmelfennig's theory that actors act strategically - On the basis of individual specific policy interests (Schimmelfennig, 2003). Therefore, by Singaporean calculations, ASEAN level interaction at the time was most in line with its n national interests, as it would mean that Singapore could share the burden of assistance among other ASEAN countries.

r.J

Schimmelfennig argues that states will strategically use norm-based arguments in pursuit of its interests (Schimmelfennig, 2001), in this case, to effectively prevent a recurrence of the haze. Several of my interviewees also explain that Singapore felt that ASEAN was the best platform for Singapore to channel pressure and help to Indonesia, without seeming overly condescending (Lim, 2010; Tay, 2010). Since the ASEAN community ethos upholds the norms of mutual respect and non-interference, Singapore was able to provide assistance to Indonesia at the ASEAN level under the understanding that this assistance observed the ASEAN norms. Singapore had hoped that Indonesia would find this level of engagement the most agreeable.

However, Schimmelfennig notes that sometimes actors would prefer to deviate from the normative standard if it contradicts its interests too seriously (Schimmelfennig, 2001). 
While Singapore understood that Indonesia suffered from capacity limitations (Quah, 2010), it observed very little positive momentum from Indonesia as a result from ASEAN level engagement, especially with the slow takeoff of the Regional Haze Action Plan (RHAP) and the Agreement on Transboundary Haze Pollution (ATHP). As a result, Ghani (2010) observed a lot of unhappiness from Singaporean officials towards the Indonesian government at ASEAN level meetings. The officials in short felt that Singaporean interests were threatened. Primarily fuelled by the governmental stalemate over Indonesia's nonratification of the ATHP, the Singaporean government began to work outside the regional framework, and put more emphasis on various alternative forms of engagement with Indonesia (Mulchand, 2010).

The first of these were bilateral arrangements with Indonesia, which involved sending direct assistance, primarily in the form of equipment, to Indonesia, circumventing the regional agreements that were already in place at the time. The second strategy used by Singaporean was to engage with Indonesia on the civil society, or track-two level. The Singaporean government supported and encouraged transnational advocacy which was hoped to surpass Indonesian government gatekeepers, or at least to ensure that Singapore's voice was heard through a less adversarial source. The third strategy was to go directly to provoke Indonesian action through the international level; at the United Nations. This was the most controversial among the three strategies, and resulted in a cooling of relations between the countries.

The adverse reactions of Indonesia towards these various strategies show proof of what Schimmelfennig calls the 'community trap' (Schimmelfennig, 2001), where Indonesia, even in at the bilateral or international level, expects Singapore to honour the ASEAN community norms, and felt it appropriate to react strongly when these norms were broken. As a result, it can be observed that Singapore's forthcoming engagements with Indonesia, namely the Singapore-Jambi master plan which was a direct bilateral engagement involving direct cooperation between Singapore and an Indonesian province at sub-state level, was careful to observe the norms of the ASEAN, to appease Indonesia. This is in line with Schimmelfennig's argument that actors may be forced to honour norm-based commitments in order to protect their credibility and reputation as neighbours in the larger community. The following sections illustrate the above discussion.

\section{Regional Cooperation}

The Singaporean public and media frequently called for its government to initiate consultation and cooperation with Indonesia to address the haze since 1972. In addition, in a 1985 Workshop on Transboundary Pollution of Haze in ASEAN Countries, the Singapore country paper contained suggestions for various ASEAN-level projects to mitigate the haze. However, the Singaporean seeds of multilateral cooperation to address the haze were only sown in 1994, when Singapore realised that nothing further could be done at home to reduce the impact of the haze on the island. 
The haze was then placed as a major item on the agenda of the Malaysia-Singapore Joint Committee on the Environment (MSJCE). At the meeting, the two countries agreed to submit a proposal to the Informal ASEAN Ministerial Meeting on the Environment for a regional early warning system for monitoring the haze, since the haze was an issue in more than one country in the region. This proposal was subsequently adopted by ASEAN, and the alert system was activated for the first time in September 1995. However, substantial ASEAN level cooperation over the haze only began in 1997, when the ASEAN countries established the Regional Haze Action Plan. The RHAP also expanded the Singapore-based ASMC's role to include haze monitoring (Yong, 2005), with Singapore bearing the running costs as a form of contribution to the region.

Despite this, Singapore still felt the need for a more concrete regional agreement. The MOHA Minister was reported to have informally mooted the idea of a regional agreement on the haze in 1998, but openly expressed his disappointment that there was absolutely no support for it at the ASEAN level. He also stated that current regional agreements (1) were disappointing (referring to the RHAP), as there were no provisions for penalties or compensation, and were just unenforceable statements of intent (The Straits Times, 1998).

After five years of negotiations, Minister Yeo's wish for a regional agreement was fulfilled when in 2002 ASEAN environmental ministers signed the ASEAN Agreement on Transboundary Haze Pollution (ATHP) (Ahmad, 2002). The Singaporean MEWR Minister at the time, Lim Swee Say, was optimistic of the treaty, saying that it was a clear expression of political will and commitment for partnership in ASEAN to prevent future occurrences of the haze (Pereira, 2002). Simon Tay (2007)was also optimistic, commenting that ASEAN Psigns very few treaties, so when a treaty is negotiated, all member countries would usually - take it very seriously. To show its support for the ATHP, Singapore was the first to voluntarily - offer a contribution of USD50,000 towards the ASEAN ATHP Haze Fund.

- Dr Alan Tan (2010) of the National University of Singapore that was interviewed points out that the non-interference norm had infiltrated the ATHP; diluting it in hopes that Indonesia Would ratify it. However, ratification from Indonesia did not immediately follow. While Singapore acknowledged that it is Indonesia's sovereign right whether or not to ratify the treaty, Singaporean officials were baffled over Indonesia's refusal because the agreement did not contain any punitive measures, and Indonesia would be able to benefit from this agreement as well (Caballero-Anthony, 2010). Singapore on several occasions hosted the Indonesian Environment Minister and his staff at the island to speed up the process of ratification. And in 2006, Singapore and Malaysia issued a united statement calling for a more coordinated response from ASEAN on the annual haze problem.

Simon Tay (2007) believes that Indonesia's non-ratification at the parliamentary level is aimed outwards at Singapore and Malaysia. In negotiations, Singapore tends to bundle issues together and seek tradeoffs, and this may be why Indonesia had responded by linking issues like extradition to their ratification of the ATHP (Ghani, 2010). Singapore officials 
were taken aback by these requests because these issues were not raised earlier at the formation stage of the ATHP. However the Singaporean officials note that they would be happy to discuss the inclusion of additional protocols to the ATHP, after Indonesia ratifies it.

\section{Bilateral Cooperation}

As a result of the slow progress with the RHAP, MEWR Minister Yeo Cheow Tong announced in 1998 that Singapore would provide financial and technical help to Indonesia not only on the regional level, but on a bilateral basis as well (Nathan, 1998). Even though Singapore was aware that bilateral arrangements would mean that Singapore had to bear higher costs for engagements, Singapore hoped that bilateral-level projects would enable

- the issue to move forward faster on several counts. First, there would be fewer parties to be dealt with. Second, it was hoped that, existing outside the ASEAN framework, there projects would involve less cultural baggage, in the form of the ASEAN Way norms, that may stand in the way of effective cooperation (Quah, 2010).

This year, bilateral cooperation between Singapore and Indonesia was put into action. Over

- the years, Singapore provided Indonesia with C-130 aircrafts for cloud seeding, satellite images of hot spots, hand-held global positioning systems (GPS) and laptop computers fitted with satellite communications hardware to the Indonesians (Fernandez, 1997). A 2002 meeting between Singapore and Indonesia resulted in a bilateral agreement that involved Indonesian officials being brought to Singapore for training to interpret these satellite images.

These pictures were reportedly made use of by Indonesia when planning ground operations to locate and control fires. It was reported however that this assistance was greeted with some displeasure on the Indonesian side, for portraying that Indonesia's remote sensing officials were not getting credit for their own remote sensing efforts (Sim, 1997), and also with concerns that Singapore was trying to rob Indonesia of its right to development (Lim, 2010). Singaporean officials also reported instances where Indonesian officials had reminded them that they should at least be thankful to Indonesia for the oxygen that they were providing for Singapore.

Singapore had also offered to assist in the form of table-top exercises to help farmers in land-clearing methods, as well as fire fighting assistance. However, Singaporean officials acknowledge that sending firefighters to Indonesian territory may be too sensitive, because these firefighters, like policemen and soldiers, could be perceived as an extension of the Singaporean state. The MOFA spokesperson reminded the public that it would be up to Indonesia on whether to accept Singapore's assistance, and assistance would have to be under Indonesian terms (Channel NewsAsia, 2006).

\section{Track-Two Diplomacy}

Faced with Indonesia's less than favourable responses to Singapore's regional and bilateral efforts, the Singaporean government attempted to use a non-official voice to express its views on the fires in Indonesia. This was done through a strong governmental support for 
NGO initiatives on the matter, and even an outright request by the Singaporean government for local NGOs to intervene. With support from the government, the SEC and SIIA pioneered the civil-society centered 'track-two diplomacy', in the hopes that the Indonesian government would feel more at ease discussing the haze issue at this track-two level (Francesch-Huidobro, 2008).

The SEC and SIIA jointly hosted the first International Policy Dialogue on the Southeast Asian Fires in June 1998, bringing together a good mix of representatives from international, regional and local NGOs, as well as business people and ASEAN and governmental representatives. The Singaporean government then proposed a meeting between Singaporean NGOs and the ASEAN Senior Officials for the Environment, where results of the dialogue were shared with the ASEAN ministers (Francesch-Huidobro, 2008).

Dis Following this, the SIIA continued to organize such dialogues, with several objectives. Firstly, it was hoped to allow for stronger involvement and criticism of the Indonesian regime by international NGOs. Second, since direct bilateral talks on haze and fires between governments may not always be possible, this task could be taken up by the local NGOs through these dialogues instead. Thirdly, since governments are usually averse to purely environmental advocacy and activism, these dialogues would instead promote action through intellectual policy exchanges and recommendations. The SIIA has been credited for 'mainstreaming' the haze in ASEAN (Lim, 2010). This is because NGOs have more of a 'philanthropic; image as compared to government which may be motivated by national interests (Geh, 2010). The latest SIIA dialogue bringing together environmentalists, private sector leaders and academics in the region, was held in October 2010 (Cheam, 2010). Government officials attending these dialogues usually do not give official statements Cor use the dialogue as a platform to grandstand government agenda, but instead uses the dialogues to gauge the sentiment of the region, which they will then take back to their senior - officials as background knowledge to consider during policy-making. This way, it is hard to gauge the effectiveness of this track-two diplomacy, but Singaporean officials described these track-two dialogues as a 'powerful pillar' and were especially valuable for being able to bring to the table both government and ASEAN officials for open discussion without the diplomatic formalities (Lim, 2010).

Among the 'sensitive' issues that were able to be raised at these dialogues was the fact that President Sukarnoputri was not supportive of environmental issues, the lack of coordination and cooperation across different ministries and agencies in Indonesia, the problem of law enforcement, corruption and collusion between government agencies and private enterprises, and inequitable land tenure agreements that do not promote ownership, and thus responsibility, of land (Francesch-Huidobro, 2008).

\section{The United Nations Affair}

Parallel to these efforts, Singapore had also been discussing in parliament about UN involvement in the haze matter since 1998 (Francesch-Huidobro, 2008). Things came to a head in 2006 when, in response to the statements of some Indonesian leaders that nothing 
could be done about the haze except to wait for a change in weather conditions, Singapore's charge d'affaires in New York responded by describing these remarks as 'profoundly shortsighted' (Garekar, 2006).

Diplomatic tensions ran high at the end of 2006, when Singapore raised the haze issue at the United Nations General Assembly, calling for a wider effort which included international expertise to tackle the problem in Indonesia. At the assembly, the Indonesian President expressed his displeasure by refusing to shake the hand of the Singaporean President (Ghani, 2010).

Indonesia's representative at the assembly, Adiyatwidi Adiwoso Asmady, stated the haze was a domestic problem and described the move as unforgivable and tantamount to interference in the domestic affairs and sovereignty of Indonesia. Asmady felt that Singapore misused 'the UN forum in a frenzy of naming and shaming'. She suggested that there might have been 'some malice' behind Singapore's actions, saying that Singapore should have honoured the outcomes of ASEAN meetings that had agreed to handle the issue bilaterally and at the ASEAN level. It expressed its unhappiness by summoning Singapore's envoy to Jakarta, and boycotting a bilateral meeting on a special economic zone between the states. Indonesia also banned the export of Indonesian sand to Singapore, saying that sand mining in Indonesian islands had caused environmental degradation there. Jakarta favoured the problem to be dealt with on the ASEAN level alone, without worldwide assistance, as Indonesian experts felt that they had adequate expertise within ASEAN to do so. Jakarta felt that it was unfairly singled out as the 'only' culprit, and felt that Singapore's move would also cost ASEAN's credibility. Several of my interviewees explain that Indonesia sees ASEAN as the most comfortable 'level of interference' for Indonesia, as compared to the international level, mainly because of the non-interference norm that can be called into force when necessary (Koh, 2010).

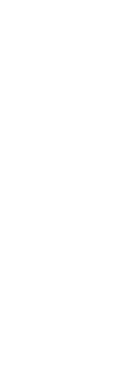

However Singapore defended its move, saying that it was not meant to shame Indonesia, but to mobilise the international support that was needed, as Singapore did not believe that the problem could be solved without international support. Singapore also pointed out that Article 2 of the ATHP specifically mentions that transboundary haze pollution should be prevented and monitored 'through concerted national efforts and intensified regional and international cooperation'. The MEWR Minister said that it would take strong resolve from the Indonesian government to enforce their laws to prevent forest fires, with support from both ASEAN and the international community (Gunasingham, 2009b). It was also pointed out that the haze was an intrusion into the domestic environment of Singapore. It was noted that Singapore originally wanted to raise the issue as a joint ASEAN statement, but Indonesia was against the idea (Garekar, 2006).

The following year in 2007, Singapore again raised the issue at the United Nations Climate Change Conference 2007 (COP 15), in Bali. Indonesia, the host country, was relatively more gracious about these comments this year. On the heels of these two diplomatic events, 
Indonesia received dreaded remarks from the UN about their non-ratification in 2009. A top UN official stated at a conference in Singapore that Indonesia needed to ratify the ATHP to prove its commitment, political will and moral obligation in tackling climate change through fighting forest fires. The official derided Indonesia's Forestry Minister's comments that action would only be taken if its neighbours complained (The Straits Times, 2009).

\section{The Singapore-Jambi Project}

In 2006, Indonesia invited its ASEAN neighbours to 'adopt' its fire-prone districts as part of its national action plan against the haze. Singapore commended the move, stating that this type of direct bilateral assistance to the grassroots level was better than a blanket ASEAN plan, and that it shows Indonesia's willingness to move forward on the issue (Lee, 2006). Singaporean officials feel that it would be easier and more expedient to achieve results on a bilateral level instead of a regional level (Lim, 2010). Singapore later committed to adopting the district of Jambi (McIndoe, 2006) (See Illustration 1) (PNPM-PSIEW, 2009).
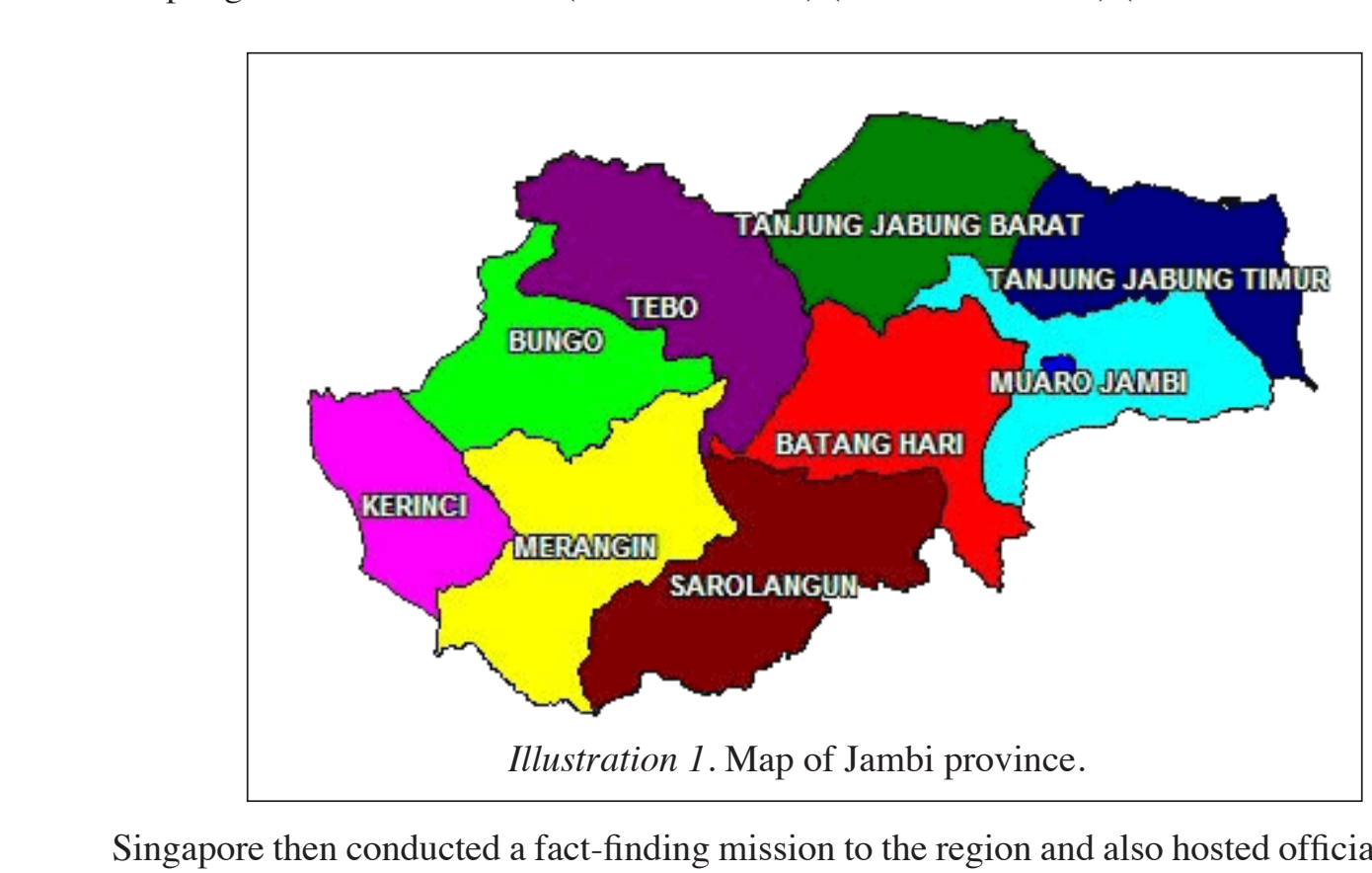

Singapore then conducted a fact-finding mission to the region and also hosted officials from Jambi for a bilateral workshop to put together the framework of the master plan (Selamat, 2007). The letter of intent (LOI) for the Jambi master plan was presented to Indonesia in early 2007 (Ghani, 2007a). Based on Indonesia's request, the master plan focused on Muaro Jambi, one of the nine regencies in the province. It sets out a two-year capacity-building strategy for land clearing without the use of fire, as well as the mitigation of peatland fires, with a focus on fire prevention. Under the master plan, Singapore would assist in funding, technical expertise, and assistance to implement seven specific programmes, if requested by Indonesia (National Environment Agency, 2009). In November 2007, Indonesia finally approved Singapore's LOI for a Jambi master plan (Chow, 2008). 
The Singaporean government was careful to point out that the Jambi provincial government would have ownership over the plan (Ghani, 2007a). And in line with the ASEAN value of non-interference, both central and local government approval has to be sought before the implementation of any collaborative projects (Sun, 2010). The emphasis on ownership was crucial as any suggestions of foreigners taking charge of Indonesia's problems was a sensitive issue for Indonesia. Particularly sensitive was Singapore's proposed plan to get international environmental bodies with expertise on peatland management to help Jambi (Ghani, 2007b). Several of my interviewees believe that Indonesia is using the norm of sovereignty to avoid having to open its doors to unwanted external scrutiny on their internal practises (Koh, 2010; Tan, 2010). Singapore's MEWR minister acknowledged this concern, stating that one could not expect countries to act against its own interests (Tan, 2007). Sachindhanam of SEC (2010) pointed out during her interview that due to the nature of this collaboration, the success of the plan is essentially dependent on the Indonesian government.

The governor of Jambi, Zulkifli Nurdin, was especially receptive to Singapore's assistance. During project handover ceremonies, he echoed the president's apology over the haze situation to Singapore, and expressed that he was looking forward to more collaboration programmes with Singapore (National Environment Agency, 2009). However, several of my interviewees note that it is difficult to determine if there was any follow through on the Indonesian side after the completion of these projects. They argue that this strategy of asking for more help from Singapore may be a way for the central and provincial governments to avoid having to take any real, internally motivated action.

- Singapore was heartened to be able to report that there were no fires in the Muaro Jambi area in 2009, where their bilateral programmes with the district was concentrated (Huang, 2009). The MOFA Minister added that the ongoing bilateral cooperation, based on 'genuine friendship and close relationship built up over the years between officials from both countries' had helped reduce the haze problem since the bad episode in 2006 (Peh, 2006). Singapore hoped that other regional heads would be encouraged by what is happening between Jambi and Singapore, and put such programmes into place as well (Gunasingham, 2009b). However, Singapore reminded Indonesia that the efforts in Jambi represent only a small part of a much larger challenge faced by Indonesia, which will require substantial political will from the Indonesian government (Koh, 2010).

\section{Conclusion}

Singapore's experience engaging with Indonesia on various levels over the haze has been a taxing one for both countries. Schimmelfennig argues that actors will often justify their interests on the basis of the community ethos, which he calls 'rhetorical action' (Schimmelfennig, 2003). Accordingly, several of my interviewees often feel that certain ASEAN norms, like sovereignty and non-interference, have empowered and emboldened Indonesia to defend and justify its non-cooperative actions or non-action over haze issues 
(Ghani, 2010; Tay, 2010), even though these actions may have been motivated by national interests, and not primarily because it would be socially accepted to do so (Schimmelfennig, 2003). However, Euston Quah of NTU (2010) warns that the Indonesian government may have underestimated the cost of goodwill among other ASEAN governments, especially of Singapore, as a result of the haze.

The numerous haze episodes over the decades have had a lasting effect on the Singaporean people's psyche. Singaporeans have come to realise that their small country is very vulnerable to its surrounding regional environment (Geh, 2010). A survey conducted recently by the SEC found that the majority of Singaporeans are acutely aware of how any internal action could have serious environmental effects its neighbouring countries. Researchers account this awareness due to the country's experiences with Indonesia's fires and the resulting haze. With the return of the haze in 2010, it remains to be seen if the continued strategic actions of Singapore, and Indonesia's strategic responses, would play out negatively or positively for the regional environment.

(1)

口

$\varepsilon$

\section{References}

Acharya, A. (2003). Democratization and the prospects for participatory regionalism in Southeast Asia. Third World Quarterly, 24(2), 375-390.

Ahmad, R. (2002, June 11). Asean inks landmark deal to battle haze. The Straits Times.

-

B Byramji, N. (1972, October 13). Change in wind direction blows away the haze. New Straits Times Singapore.

10

Caballero-Anthony [S3], M. (2010, May 13). Head, Centre for Non-Traditional Security Studies, NTU.

Haze worsens in Singapore, PSI hits new high for the year. (2006, October 7). Channel NewsAsia.

Channel NewsAsia. (2010, October 20). Quick meeting among ASEAN ministers needed if haze worsens, Channel NewsAsia.

Cheam, J. (2010, October 28). Paying locals to protect forests may help end haze. The Straits Times.

Chow, K. H. (2008, April 9). Five Asean nations step up efforts to fight haze. The Straits Times.

Chua, M. H. (1997, October 5). THE BIG HAZE - No need for Singapore to shout. The Straits Times. 
Fernandez, W. (1997, September 29). S'pore playing active role in fighting haze. The Straits Times.

Francesch-Huidobro, M. (2008). The power of circumvention: Fighting the Southeast Asian forest fires and haze. Governance, politics and the environment: A Singapore study. Singapore: Institute of South East Asian Studies.

Gan, T. L. (1972). Smoke haze over Singapore. Meteorological Service Singapore.

Garekar, B. (2006, November 7). Singapore defends move to raise haze issue at UN. The Straits Times.

Geh [S25], M. (2010, June 9). Former President. Nature Society Singapore .

Ghani [S6], A. (2010, May 17). Former Straits Times Press Reporter.

- Ghani, A. (2006, October 12). Yudhoyono says sorry to S'pore. Malaysia for haze. The Straits Times.

Ghani, A. (2007a, June 23). S'pore-Jakarta anti-haze project 'progressing well'. The Straits Times.

Ghani, A. (2007b, June 20). Singapore and Malaysia update Asean haze plans. Straits Times.

Gunasingham, A. (2009a, September 17). Haze worsens. The Straits Times.

Gunasingham, A. (2009b, September 16). Joint efforts with fire-prome provinces help to ease haze. The Straits Times.

Hadhi, A. (1994, September 28). S'pore holding talks with KL and Jakarta on haze problem. The Straits Times.

Hon, P. M. L. (1999). Singapore. In D. Glover \& T. Jessup (Eds.), Indonesia's fires and haze: The cost of catastrophe. Singapore: Institute of Southeast Asian Studies.

Huang, H. F. (2009, February 22). S'pore not affected by haze in Sumatra. The Straits Times.

Katsumata, H. (2004). Why is ASEAN diplomacy changing?: From non-interference to open and frank discussions. Asian Survey, 44(2), 237-254.

Koh [S2], K. L. (2010, May 13). Director, Asia Pacific Centre for International Law, NUS. 
Lee [S20], P. O. (2010, May 26). Fellow, regional economic studies. Institute for South East Asian Studies.

Lee, L. (2006, November 6). Asean needs help to tackle haze: PM. The Straits Times.

Liang, H. T. (2000, August 6). Singapore, Malaysia to monitor impact of haze. The Straits Times.

Lim [S13], M. A. (2010, May 18). Manager, Policy Research, Singapore Institute of International Affairs.

McIndoe,A. (2006, November 10). Five Asean countries approve anti-haze plan. The Straits Times.

Mulchand [S21], A. (2010, May 26). Former environmental reporter. Straits Times Press.

Nathan, D. (1998, April 6). Asean gets UN to help keep haze out. The Straits Times.

-

National Environment Agency. (2009). Indonesia-Singapore collaboration to deal with the land and forest fires in Jambi province. Singapore: National Environment Agency.

Peh, S. H. (2006, November 15). Haze: No all-celear yet, but it's getting better. The Straits Times.

Pereira, D. (1997, September 17). The big haze - S'pore "encouraged" by efforts to douse (1) fires. The Straits Times.

Pereira, D. (2002, June 12). Asean eager to make success of anti-haze treaty. The Straits Times.

Phelps, N. A. (2004). Archetype for an archipelago? Batam as an anti-model and model of industrialisation in reformasi Indonesia. Progress in Development Studies, 4(3), pp. 210-218.

PNPM-PSIEW. (2009). Peta Jambi, Retrieved 2 December 2010

Quah [S24], E. (2010, June 8). Head of Economics, NTU.

Savage [S9], V. R. (2010, May 18). Lecturer, Department of Geography, NUS.

Schimmelfennig, F. (2001). The community trap: Liberal norms, rhetorical action, and the Eastern enlargement of the European Union. International Organization, 55(1), 47.

Schimmelfennig, F. (2002). Goffman meets IR: Dramaturgical action in international community. International Review of Sociology, 12(3). 
Schimmelfennig, F. (2003). Strategic action in a community environment. Comparative Political Studies, 36(156).

Selamat, F. (2007, March 10). Dousing Indonesia's hotspots: S'pore, Jambi launch masterplan to stop haze-causing fires in province. Today.

Sim, S. (1997, October 7). Jakarta says S'pore satellite maps 'useful' in tacking haze. The Straits Times.

Smith, A. (1999). Indonesia's role in ASEAN: The end of leadership? Contemporary Southeast Asia, 21(2).

田

Soeriaatmadja, W. (2009, February 19). Haze in Riau heading for Singapore. The Straits Times.

Sun [S17], D. (2010, May 25). CEO, Carbon Conservation.

- Tan [S7], A. K. J. (2010, May 17). Vice Dean, Faculty of Law, NUS.

Tan, T. (2007, August 18). Haze fight: S'pore to work with slash-and-burn farmers. The Straits Times.

Tay [S12], S. (2010, May 18). Chairman, Singapore Institute of International Affairs.

Tay, S. (1997, October 1). The haze and Asean cooperation. The Straits Times.

The Straits Times. (1998, March 17). BUDGET - S'pore and WHO to study impact of haze

The Straits Times. (1998, March 17). BUDGET - S'pore and
long-term effect on people's health. The Straits Times.

- The Straits Times. (2009, October 15). Indonesia 'should ratify haze pact'. The Straits Times.

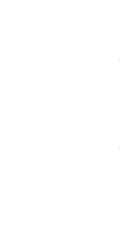

Wee, P. (1973, July 21). Factory smoke blamed for haze. The Straits Times.

Woon, S. L. (2002). Monitoring and remote sensing in ASEAN: ASMC's role, capacities and activities in relation to ASEAN's regional haze action plan. Paper presented at the World Land \& Forest Fire Hazards, Kuala Lumpur.

Yong, M. K. (2005). Monitoring and assessment of land/forest fires and smoke haze in ASEAN Workshop on Multi-Hazard, Early Warning Center's Concept of Operations for the Indian Ocean Tsunami Warning System. Singapore: World Meteorological Organization. 


$$
\begin{aligned}
& \text { हे } \\
& \text { כ } \\
& \overline{0} \\
& \text { (1) } \\
& \frac{\varepsilon}{\Xi} \\
& \text { ( ) } \\
& \sqrt{\square \quad} \\
& \text { 음 } \\
& \text { 政 } \\
& \text { ع }
\end{aligned}
$$

